\title{
Increased cell viability and proliferation in post-hypoxic hippocampal tissue culture treated with Acalypha indica root extract
}

\author{
Sophie Yolanda, ${ }^{1}$ Endang W. Bachtiar, ${ }^{2}$ Nurhadi Ibrahim ${ }^{1}$ \\ ${ }^{1}$ Department of Physiology, Faculty of Medicine, University of Indonesia, Jakarta, Indonesia \\ ${ }^{2}$ Department of Oral Biology, Faculty of Dentistry University of Indonesia, Jakarta, Indonesia
}

\begin{abstract}
Abstrak
Latar belakang: Studi ini dilakukan untuk mempelajari pengaruh pemberian ekstrak akar Acalypha indica Linn terhadap viabilitas relatif dan proliferasi sel sebagai parameter neurogenesis pada kultur jaringan hipokampus tikus pascahipoksia.

Metode: Studi eksperimental in vitro pada 24 kultur primer jaringan sel saraf tikus Sprague Dowley dewasa yang dipajankan terhadap hipoksia dengan gas 5\% O2/5\% CO2/N2 seimbang selama 24 jam. Pascahipoksia, ekstrak Acalypha indica Linn ditambahkan pada 3 kelompok perlakuan, masing-masing dengan dosis 10, 15, dan $20 \mathrm{mg} / \mathrm{mL}$, sedangkan pada kelompok kontrol tidak ditambahkan apapun. Setiap kelompok terdiri atas 6 sampel. Setelah inkubasi selama 90 jam, viabilitas relatif sel diukur dengan 3-(4,5-dimethylthiazol-2-yl)-2,5-diphenyltetrazolium bromide (MTT), proliferasi sel diukur dengan 5-bromo2'-deoxy-uridine (BrdU). Data dianalisis dengan menggunakan tes parametrik one way ANOVA yang dilanjutkan dengan analisis post-hoc.

Hasil: Viabilitas relatif sel pada kultur jaringan hipokampus tikus pascahipoksia dengan pemberian ekstrak akar kucing pada dosis 10, 15, dan $20 \mathrm{mg} / \mathrm{mL}$ lebih tinggi secara bermakna dibandingkan dengan kontrol (176,95\%, 220,62\%, 386,02\% vs. $100 \%)$. Proliferasi sel pada kultur jaringan hipokampus tikus pascahipoksia dengan pemberian ekstrak akar kucing pada dosis 10, 15, dan 20 mg/mL lebih tinggi secara bermakna dibandingkan dengan kontrol (0,132; 0,117; 0,114 vs. 0,096).

Kesimpulan: Ekstrak Acalypha indica Linn dapat meningkatkan viabilitas relatif dan proliferasi sel pascahipoksia in vitro pada dosis 10, 15, dan $20 \mathrm{mg} / \mathrm{mL}$. (Med J Indones 2011; 20:94-9)
\end{abstract}

\begin{abstract}
Background: This research was done to study the influence of Acalypha indica Linn root extract towards relative cell viability and proliferation as parameters of neurogenesis in post-hypoxic hippocampal tissue culture.

Methods Experimental in vitro study using 24 primary neuronal cell cultures obtained from adult Sprague Dawley rat exposed to hypoxia with 5\% O2/5\% CO2/N2 balance gas for 24 hours. Post-hypoxia, Acalypha indica Linn root extract was added at doses of 10,15 , and $20 \mathrm{mg} / \mathrm{mL}$ to 3 treatment groups. No treatment was given to the control group. Each group consists of 6 samples. After 90 hours of incubation, relative cell viability was measured by using 3-(4,5dimethylthiazol-2-yl)-2,5-diphenyltetrazolium bromide (MTT) examination, and cell proliferation was measured by using 5-bromo2'-deoxy-uridine (BrdU) for cell proliferation. Data was analyzed using one way ANOVA parametric tests, then further analyzed with post-hoc analysis.

Results: The relative cell viability of rat hippocampal tissue culture treated with Acalypha indica Linn root extract with dose of 10, 15, and $20 \mathrm{mg} / \mathrm{mL}$ was significantly higher than control (176.95\%, 220.62\%, and 386.02\% vs. 100\%). Cell proliferation of rat hippocampal tissue culture treated with Acalypha indica Linn root extract with dose of 10, 15, and $20 \mathrm{mg} / \mathrm{mL}$ was significantly higher than control (0.132, 0.117, $0.114 \mathrm{vs} 0.096)$.

Conclusion: Acalypha indica Linn root extract with doses of 10, 15, and $20 \mathrm{mg} / \mathrm{mL}$ can increase relative cell viability and proliferation in post-hypoxic hippocampal tissue culture. (Med J Indones 2011; 20:94-9)
\end{abstract}

Key words: Acalypha indica Linn (akar kucing), cell proliferation, hypoxia, neurogenesis, relative cell viability

Currently, the primary therapy for ischemic stroke is administration of thrombolytics, ${ }^{1}$ because this is the only therapeutic approach that showed improvement of neurological function. ${ }^{2}$ Unfortunately, the 3-hour therapeutic window for this therapy is very brief, ${ }^{1}$ and it will increase the risk of hemorrhagic transformation. ${ }^{3}$ This is why neurorestorative therapy with longer therapeutic window and actively improving neurological function to restore and optimize the brain function is necessary. ${ }^{2,3}$ Neurorestorative therapy will enhance the development of new nerve cells (neurogenesis) in the post stroke ischemic brain tissue. ${ }^{3}$ In most adult mammalian brain, there are stem cells in the subgranular zone (SGZ) dentate gyrus (DG) of the hippocampus and subventricular zone (SVZ) of the lateral ventricle. ${ }^{2,4,5}$ These stem cells can be stimulated by a variety of physiological and pathological factors such as hypoxia. ${ }^{4,5}$ Many studies have proven the ability of adult brain neurogenesis in the post-hypoxic cerebral tissue. ${ }^{4,5}$ In humans, neurogenesis induced by stroke has been reported by Jin et al. ${ }^{6}$ Although the neurogenesis was increased naturally in the post-hypoxic cerebral tissue, the increased was not proportional to the damage that had been occurred. ${ }^{7}$

One of the causes of cell death in stroke is the process of inflammation, ${ }^{8}$ with activation of the enzyme phospholipase A2 (PLA2), which will produce arachi- 
donic acid (AA), ${ }^{9,10} \mathrm{AA}$ will be metabolized through the cyclooxygenase (COX) pathway which will convert AA into prostaglandin $\mathrm{H} 2$ (PGH2). PGH2 is the precursor of further prostaglandins, which together with various other eicosanoids may increase the permeability of the blood brain barrier and ultimately cause brain edema. ${ }^{10}$ Inflammation has been proven to inhibit the basal and post-hypoxic neurogenesis. ${ }^{11}$ One safe neurorestorative therapy approach is the mobilization of endogenous adult stem cell population in the central nervous system. These endogenous adult system cells can integrate and participate in the functional neural circuits. ${ }^{12}$ One of the methods for stem cell mobilization is the decreasing of inflammatory response. ${ }^{13}$

Acalypha indica Linn (akar kucing) is a plant that can be found in every region in Indonesia. Empirically, people have used the roots of the plant to cure nerve paralysis caused by stroke. ${ }^{14}$ Some of the active chemical compounds contained in the plant have been identified, such as kaempferol (flavonoids), betasitosterol, hydrogen cyanide, gamma-sitosterol, and acalyphin..$^{15}$ Nirmal et al. have proven that acalyphin and stigmasterol function as anti-inflammatory agents by forming PLA2 inhibitor complexes. PLA2 is an important inflammation precursor. ${ }^{16}$ As mentioned above, decreasing of the inflammatory response can increase the mobilization of endogenous adult stem cells population in the central nervous system. ${ }^{13}$

Although empirically this plant has been used to cure paralysis in post-stroke patients, there is no scientific evidence yet on the effects of Acalypha indica Linn root extract on post-stroke neurogenesis. There are many parameters to measure neurogenesis, two of them are the relative cell viability and proliferation. ${ }^{17}$ This research is aimed to observe the effect of Acalypha indica Linn root extract on relative cell viability and proliferation as parameters of neurogenesis in the posthypoxic hippocampal tissue in vitro.

\section{METHODS}

\section{Study design and sample}

An in vitro experimental study was conducted on primary neuronal cell cultures, which were taken from the hippocampus of adult Sprague Dawley rats aged 9-10 weeks weighing 200-250 grams. The experiment was conducted at the Oral Biology Laboratory, Faculty of Dentistry University of Indonesia from January to March 2010. The animals were sacrificed by cervical dislocation. The total number of samples was 24, divided equally into 4 groups (1 control group and 3 treatment groups) based on Federer formula. Ethical clearance was obtained from the committee of the medical research ethics of the Faculty of Medicine, University of Indonesia, and the management of animals used was in accordance to the Helsinki convention.

\section{Culture of nerve cells}

Nerve cells were cultured in petri dishes that have been coated with poly-L-lysine (Nacalai Tesque, Jakarta, Indonesia) for 1 hour. The nerve cells were then seeded into $1 \times 10^{6}$ cells/dish. Cultures were incubated (Inco 2 Memmert) with $5 \% \mathrm{CO} / 95 \%$ air at $37^{\circ} \mathrm{C}$. Dulbecco's Modified Eagle Medium (DMEM) (GIBCO, Invitrogen, Jakarta, Indonesia) was used for culture medium and was replaced every 72 hours during the incubation period.

\section{Cell harvest and plating}

Nerve cell cultures were harvested on day 10 and identified morphologically. The number of cells was counted using trypan blue and a hemocytometer. The nerve cells were then seeded into 24 well-plates at $5 \times 10^{5}$ cells/well and into 96 well-plates at $1 \times 10^{5}$ cells/ well, respectively. The multiwell culture plates had previously been coated with poly-L-lysine for 1 hour.

\section{Exposure to hypoxia}

Directly after plating, nerve cells were then exposed to hypoxia by administering 5\% O2/5\% CO2/N2 balance gas for 24 hours. ${ }^{18}$

\section{Treatment with Acalypha indica Linn extract}

Each treatment groups of nerve cell cultures were given Acalypha indica Linn root extract with doses of 10,15 , and $20 \mathrm{mg} / \mathrm{mL}$. The control group was given no treatment. Acalypha indica Linn root extract was obtained from Department of Pharmacy, Faculty of Medicine University of Indonesia. The plates were reincubated with $5 \% \mathrm{CO} 2 / 95 \%$ air at $37^{\circ} \mathrm{C}$ for 90 hours.

\section{Measurement of relative cell viability and proliferation}

Relative cell viability and cell proliferation are two parameters of neurogenesis. ${ }^{17}$ Relative cell viability was measured using 3-(4,5-dimethylthiazol-2-yl)-2,5diphenyltetrazolium bromide (MTT) examination from SIGMA. MTT assay was performed in triplicate. The result of MTT test indicates the number of post-hypoxic viable nerve cells, but the viable cells can be derived from new nerve cells resulting from neurogenesis or old nerve cells that survive post-hypoxia and did not undergo apoptosis. Therefore BrdU examination to assess the level of cell proliferation was performed. Cell proliferation was measured using 5-bromo2'-deoxy-uridine (BrdU) (Roche, Jakarta, Indonesia). BrdU examination was performed in duplicate. Cells from the 24 well-plates were used for MTT examination; cells from the 96 wellplates were used for BrdU examination. 


\section{Data analysis}

Normality of data was tested by using Shapiro-Wilk test. Relative cell viability and cell proliferation data was compared between control and each treatment group by using one way ANOVA parametric test, and further analyzed with post-hoc analysis. Data processing was performed using Statistical Package for the Social Sciences (SPSS) version 16.0 software.

\section{RESULTS}

\section{Relative Cell Viability}

Mean relative cell viability in the control group was set to $100 \%$, with values between 85.01 and 115.08 $(\mathrm{SD}+/-14.33, \mathrm{n}=6)$. In groups treated with Acalypha indica Linn extract at doses of 10,15 , and $20 \mathrm{mg} / \mathrm{mL}$ of extract, respectively, mean cell viability was $176.95 \%$ with values between 168.0 and 185.29 (SD +/- 7.95, n = 6), $220.62 \%$ with values between 168.7 and 272.54 (SD +/- 49.47, $\mathrm{n}=6$ ), $386.02 \%$ with values between 339.65 and 432.39 (SD +/- 44.16, $n=6$ ), consecutively $(\mathrm{p}=0.000$ in all treatment groups vs control; Fig. 1).

The relative cell viability in group treated with extract at dose of $15 \mathrm{mg} / \mathrm{mL}$ was significantly higher than the relative cell viability in group treated with extract at dose of $10 \mathrm{mg} / \mathrm{mL}$ ( $\mathrm{p}=0.021$ ), and the relative cell viability in group treated with extract at dose of 20 $\mathrm{mg} / \mathrm{mL}$ was significantly higher than the relative cell viability in group treated with dose of $15 \mathrm{mg} / \mathrm{mL}(\mathrm{p}=$ 0.000; Fig. 1).

\section{Cell proliferation}

Absorbance in the control group was 0.096 with values between 0.089 and $0.103(\mathrm{SD}+/-0.007, \mathrm{n}=6)$. In groups treated with Acalypha indica Linn extract at doses of 10, 15 , and $20 \mathrm{mg} / \mathrm{mL}$, respectively, absorbance was 0.132 with values between 0.122 and 0.141 (SD +/- 0.009, $\mathrm{n}$ $=6$ ), 0.117 with values between 0.109 and 0.124 (SD $+/-0.007, \mathrm{n}=6), 0.114$ with values between 0.103 and 0.125 (SD +/- 0.01, $\mathrm{n}=6$ ), consecutively ( $\mathrm{p}=0.000$, 0.000 , and 0.002 in groups treated with extract at doses of 10, 15, and $20 \mathrm{mg} / \mathrm{mL}$, respectively; Fig. 2).

The highest cell proliferation level was seen in group treated with extract at dose of $10 \mathrm{mg} / \mathrm{mL}$. The cell proliferation decreased significantly in groups treated with extract at doses of 15 and $20 \mathrm{mg} / \mathrm{mL}$ ( $p=0.005$ and 0.001 , respectively), but no significant difference was found in the cell proliferation level between groups treated with extract at doses of 15 and $20 \mathrm{mg} / \mathrm{mL}$ ( $p=0.568$; Fig. 2).

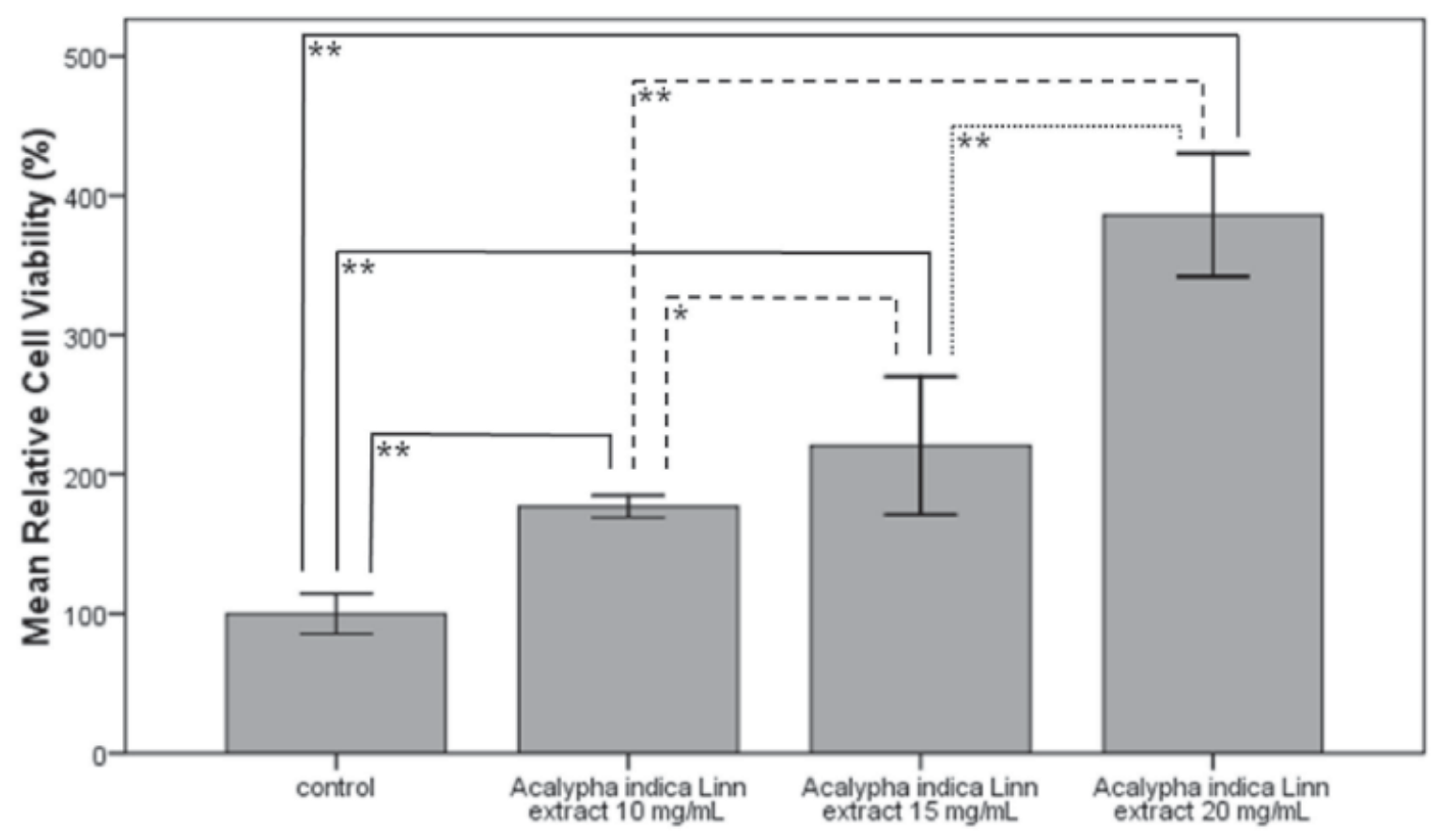

Figure 1. Comparison of mean of relative cell viability between control group with treatment groups given Acalypha indica Linn root extract with consecutive doses of 10,15 , and $20 \mathrm{mg} / \mathrm{mL}$

$* \mathrm{p}<0.05 \quad * * \mathrm{p}<0.01$ 


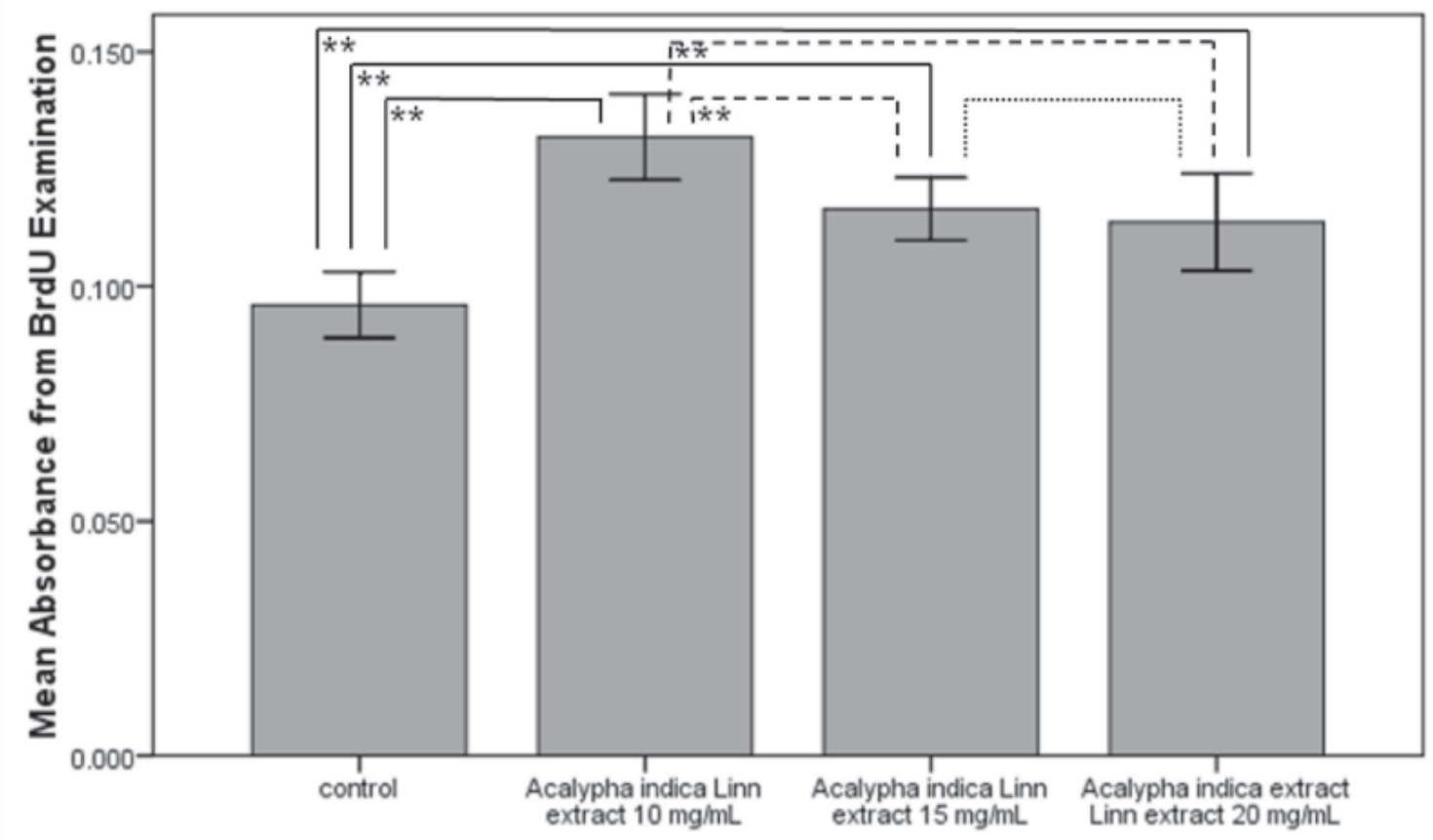

Figure 2. Comparison of mean of 5-bromo2'-deoxy-uridine (BrdU) absorbance between control group with treatment groups given Acalypha indica Linn root extract with consecutive doses of 10, 15, and $20 \mathrm{mg} / \mathrm{mL}$

$* \mathrm{p}<0.05 \quad * * \mathrm{p}<0.01$

\section{DISCUSSION}

MTT test results indicate that the relative cell viability of all treatment groups were significantly higher than control, and showed dose-dependent relationship, even up to almost 4 -fold at dose $20 \mathrm{mg} / \mathrm{mL}$. The result of this examination showed that Acalypha indica Linn root extract has an effect on increasing the number of viable post-hypoxic nerve cells. The result was consistent with research by Purwaningsih et al. ${ }^{14}$ in which the optimal neurotherapy dose was seen at dose $20 \mathrm{mg} / \mathrm{mL}$. The dose-dependent increase in relative cell viability raises the possibility that a higher dose than $20 \mathrm{mg} / \mathrm{mL}$ would further enhance the cell viability, thus further research to assess the effect of Acalypha indica Linn root extract on relative cell viability of hippocampal tissue posthypoxia with higher doses needs to be performed to obtain the optimal dose for the increase of post-hypoxic relative cell viability.

The result of BrdU examination showed that the cell proliferation level in all treatment groups were significantly higher than the control group. This means that the Acalypha indica Linn root extract has an effect on increasing the post-hypoxic cell proliferation level. The optimal cell proliferation level was found at the dose $10 \mathrm{mg} / \mathrm{mL}$, and then decreased at dose $15 \mathrm{mg} / \mathrm{mL}$ and $20 \mathrm{mg} / \mathrm{mL}$. There are two possible causes for this phenomenon. The first is that the most optimal level of cell proliferation is indeed at the dose $10 \mathrm{mg} / \mathrm{mL}$, thus the higher relative cell viability at the higher doses might be the result of old nerve cells that survive post-hypoxia and did not undergo apoptosis. This can occur due to the decrease in the inflammatory response caused by a decrease in PLA2 enzyme activation by acalyphin and stigmasterol that will further decrease the occurrence of respiratory burst and ROS production by which more cells may survive post-hypoxia. ${ }^{8}$ Stigmasterol also has antioxidant activity that can inhibit the production of ROS and ultimately improve the post-hypoxic survival of nerve cells. ${ }^{19}$ Acalypha indica Linn also contains flavonoids which possesses antioxidant activity and acts as free radicals scavenger. ${ }^{20}$ The second possibility is that at the time of examination, not all new nerve cells resulting from neurogenesis can be detected by BrdU examination. This is because incorporation of BrdU can only occur when the cells are in S phase of the cell cycle, ${ }^{21}$ thus new cells that have undergone proliferation before or which are going to undergo proliferation but were not in S phase cannot be detected by this examination. Therefore, further research with time serial BrdU examination (e.g. every 24 hours posthypoxia) needs to be performed to obtain a more accurate cell proliferation level. Examination with other cell proliferation markers can also be performed as comparison to the BrdU results, such as Ki-67 examination. ${ }^{21}$

Increased relative cell viability and proliferation that occurs in the groups treated with Acalypha indica Linn root extract is most likely caused by inhibition of PLA2 
enzyme activation that will reduce the inflammatory response. This will then increase the mobilization of adult stem cells that already exist physiologically in the central nervous system and this in turn will increase relative cell viability and proliferation. ${ }^{13}$ This mechanism was not studied in this research, thus further research to assess whether the effect Acalypha indica Linn root extract toward increased relative cell viability and proliferation post-hypoxia is caused by inhibition PLA2 activation by comparing the levels of PLA2 between treatment groups using a marker of PLA2 is needed.

Besides reduction in the inflammatory response, Acalypha indica Linn root extract may also act by increasing neurotrophic factors such as BDNF, VEGF, and bFGF. Neurotrophic factors are necessary for the survival mechanism of neuroblast. ${ }^{2}$ The increased relative cell viability and proliferation caused by Acalypha indica Linn root extract through this mechanism has not been investigated, thus further research to assess whether the Acalypha indica Linn root extract can enhance cell viability and proliferation post-hypoxia through enhanced neurotrophic factors by examining the levels of growth factors (e.g. BDNF) between treatment groups is needed.

This research has a limitation, which was the identification of the neural cells in this study was performed morphologically. This method cannot identify the neural cells with full certainty because the identified cells may be other cells also residing in the hippocampus, such as glial cells and fibroblasts. Thus, further research to positively identify the neural cells by using a specific marker or antibody such as neuron-specific enolase type 2 is needed.

From this research we can conclude that Acalypha indica Linn root extract at doses of 10, 15, and $20 \mathrm{mg} /$ $\mathrm{mL}$ can increase relative cell viability and proliferation post-hypoxia in vitro.

\section{Acknowledgments}

The research was funded by Hibah Riset Unggulan University of Indonesia (RUUI) 2009 contract number 747M/DRPM-UI/A/N1.4/2009 with dr. Nurhadi Ibrahim, $\mathrm{PhD}$ as the principal researcher. We would like to thank the staff of the Oral Biology Laboratory, Faculty of Dentistry University of Indonesia for their work during the research; Department of Physiology, Faculty of Medicine University of Indonesia and Department of Oral Biology, Faculty of Dentistry University of Indonesia for their support.

\section{REFERENCES}

1. Becker JU. Stroke, ischemic [Internet]. 2008. Available from: URL: http://www.emedicine.com/EMERG/topic558.htm.

2. Zhang RL, Zhang ZG, Chopp M. Neurogenesis in the adult ischemic brain: generation, migration, survival, and restorative therapy. Neuroscientist [Internet]. 2005 [cited 2008 Oct 8]; 11: 408. Available from: URL: http://nro. sagepub.com/cgi/content/abstract/11/5/408.

3. Ding G, Jiang Q, Li L, Zhang L, Zhang ZG, Ledbetter KA, et al. Magnetic resonance imaging investigation of axonal remodeling and angiogenesis after embolic stroke in sildenafiltreated rats. J Cereb Blood Flow Metab [Internet]. 2008 [cited 2008 Aug 24]; 28: 1440-8. Available from: www.jcbfm.com.

4. Tanaka R, Yamashiro K, Mochizuki H, Cho N, Onodera M, Mizuno Y, et al. Stroke [Internet]. 2004 [cited 2008 Sept 30]; 35: 1454-9. Available from: http://www.strokeaha.org.

5. Yagita Y, Kitagawa K, Ohtsuki T, Takasawa K, Miyata T, Okano $\mathrm{H}$, et al. Neurogenesis by progenitor cells in the ischemic adult rat hippocampus. Stroke [Internet]. 2001 [cited 2008 Sept 30]; 32: 1890-6. Available from: http://www.strokeaha.org.

6. Jin K, Wang X, Xie L, Mao XO, Zhu W, Wang Y, et al. Evidence for stroke-induced neurogenesis in the human brain. PNAS [Internet]. 2006 [cited 2008 Aug 24]; 103(35): 13198-202. Available from: URL: http://www.pnas.org cgi_doi_10.1073_pnas.0603512103.

7. Borlongan CV, Hess DC. New hope for stroke patients: mobilization of endogenous stem cells. CMAJ [Internet]. 2006 [cited 2008 Aug 24]; 174(7): 954-5. Available from: www.cmaj.ca.

8. Culmsee C, Krieglstein J. Ischaemic brain damage after stroke: new insights into efficient therapeutic startegies. EMBO reports [Internet]. 2007 [cited 2008 Aug 24]; 8: 129-33. Available from: Pubmed Central.

9. Titsworth WL, Liu NK, Xu XM. Role of secretory phospholipase $\mathrm{A}_{2}$ in CNS inflammation: implications in traumatic spinal cord injury. CNS Neurol Disord Drug Targets [Internet]. 2008 [cited 2010 Apr 11]; 7(3): 254-69. Available from: NIH Public Access.

10. Wang Q, Tang XN, Yenari MA. The inflammatory response in stroke. J Neuroimmunol [Internet]. 2007 [cited 2008 Sept 30]; 184(1-2): 53-68. Available from: NIH Public Access.

11. Ekdahl CT, Claasen JH, Bonde S, Kokaia Z, Lindvall O. Inflammation is detrimental for neurogenesis in adult brain. PNAS [Internet]. 2003 [cited 2008 Aug 24]; 100(23): 13632-7. Available from: URL: http://www.pnas.org_cgi_ doi_10.1073_pnas.2234031100.

12. Haas S, Weidner N, Winkler J. Adult stem cell therapy in stroke. Curr Opin Neurol [Internet]. 2005 [cited 2009 Feb 2]; 18: 59-64. Available from: Lippincott Williams \& Wilkins.

13. Szentirmai O, Carter BS. Genetic and cellular therapies for cerebral infarction. Neurosurgery [Internet]. 2004 [cited 2009 Feb 2]; 55(2): 283-97. Available from: www. neurosurgery-online.com.

14. Purwaningsih EH, Ibrahim N, Zain H. The nerve protection and in vivo therapeutic effect of Acalypha indica extract in frogs. Med J Indones [Internet]. 2010 [cited 2010 Apr 16]; 19:96-102. Available from: mji.ui.ac.id/v2/?page=journal. download_process\&id=68.

15. Indian Medicinal Plants Growers' Consortium. Acalypha indica L [Internet]. 2007 [cited 2009 Jan 12]. Available from: impgc.com.

16. Nirmal N, Praba GO, Velmurugan D. Modeling studies on phospholipase $\mathrm{A}_{2}$-inhibitorcomplexes. IndianJBiochemBiophys [Internet]. 2008 [cited 2009 August 31]; 45: 256-62. Available from:http://nopr.niscair.res.in/bitstream/123456789/1941/1/ IJBB\%2045(4)\%20256-262.pdf.

17. Jin K, Zhu Y, Sun Y, Mao XO, Xie L, Greenberg DA. Vascular endothelial growth factor (VEGF) stimulates neurogenesis 
in vitro and in vivo. PNAS [Internet]. 2002 [cited 2008 Aug 24]; 99(18): 11946-50. Available from: URL: http://www. pnas.org_cgi_doi_10.1073_pnas.182296499.

18. Gozal E, Sachleben Jr LR, Rane MJ, Vega C, Gozal D. Mild sustained and intermittent hypoxia induce apoptosis in PC-12 cells via different mechanisms. Am J Physiol Cell Physiol [Internet]. 2005 [cited 2010 Jan 20]; 288:535-42. Available from: www.ajpcell.org.

19. Yasukazu Y, Etsuo N. Antioxidant effects of phytosterol and its components. J Nutr Sci Vitaminol [Internet]. 2003 [cited 2010 Apr 16]; 49(4):277-80. Available from: http://www.
biomedexperts.com/Abstract.bme/14598915/Antioxidant_ effects_of_phytosterol_and_its_components

20. Georgetti SR, Casagrande R, Di Mambro VM, Azzolini AECS, Fonseca MJV. Evaluation of the antioxidant activity of different flavonoids by the chemiluminescence method. AAPS PharmSci [Internet]. 2003 [cited 2010 Apr 22]; 5(2):20. Available from: http://www.pharmsci.org.

21. Muskhelishvili L, Latendresse JR, Kodell RL, Henderson EB. Evaluation of cell proliferation in rat tissue with BrdU, PCNA, Ki-67(MIB-5) immunohistochemistry and in situ hybridization for histone mRNA. J Histochem Cytochem [Internet]. 2003 [cited 2010 Apr 14]; 51:1681-8. Available from: www.jhc.org. 